\title{
Countries' governance and competitiveness: business environment mediating effect
}

\author{
Paulo Cesar Bontempo \\ Centro Universitárrio Alves Faria, Departamento de Administração, \\ Goiania, Brazil
}

\begin{abstract}
Purpose - The purpose of this study is to analyze how institutional governance and business environment affect countries' competitiveness and their relative importance.

Design/methodology/approach - In this paper, the authors analyze how institutional governance and business environment affect countries' competitiveness, their relative importance and what are the implications for Brazil. The authors have collected data from 131 countries related to the institutional governance, business environment and competitiveness of these countries. For the analysis of the mentioned influences, the technique of partial least squares structural equations modeling is used.
\end{abstract}

Findings - Results indicate that the main role in countries' competitiveness is played by the quality of institutional governance. The quality of the business environment reinforces the positive effect of the quality of institutional governance on countries' competitiveness (mediation effect). Brazil has poor governance quality indicators when compared to high-middle income countries, especially regarding government effectiveness, political stability and control of corruption.

Research limitations/implications - The study provides a better understanding of the relative importance of governance quality and business environment quality for countries' competitiveness. One limitation of this study is that the research was restricted to data related to the year 2019.

Practical implications - For strategists and decision-makers, understanding these effects on countries' competitiveness and their relative importance is fundamental to understanding what makes their companies internationally competitive.

Social implications - The presence and appreciation of institutional governance quality need to be cultivated in society.

Originality/value - Instead of using the original diamond model, which presents circular relationships, the authors have used the business environment construct, composed of elements of the diamond model to test the relationships between the quality of institutional governance, competitiveness and the business environment.

Keywords Competitiveness, Structural equation modeling, Business environment, Mediating effect, Institutional governance

Paper type Research paper

(C) Paulo Cesar Bontempo. Published in RAUSP Management Journal. Published by Emerald Publishing Limited. This article is published under the Creative Commons Attribution (CC BY 4.0) licence. Anyone may reproduce, distribute, translate and create derivative works of this article (for both commercial and non-commercial purposes), subject to full attribution to the original publication and authors. The full terms of this licence maybe seen at http://creativecommons.org/licences/by/4.0/ legalcode.

\section{Business environment mediating effect}

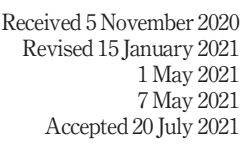

Accepted 20 July 202 (1) 
RAUSP

57,1

\section{Introduction}

The reasons why some nations develop and prosper, while others do not, are a permanent subject of interest in social sciences (Landes, 1998).

Porter (1990) applied the concept of competitiveness to the scope of nations to explain the existing differences in countries' competitiveness (Diamond Model). In a later study, Porter, Delgado, Kettels and Stern (2008) defined the business environment concept based on the elements of the Diamond Model. For the authors, the influence of other factors on countries' competitiveness such as government actions, would occur through their respective business environments.

Research-based on the institutional perspective (North, 1990) identifies institutional governance as the most important factor for differences in prosperity between countries (Hall \& Jones, 1999; Acemoglu \& Robinson, 2010). Institutional governance concerns the traditions and institutions by which authority in a country is exercised, governments are selected, monitored, replaced and implement effective policies respecting the institutions that govern economic and social interactions (World Bank, 2019a).

Lee (2010) identified the need to update the Diamond Model by incorporating insights from institutional theory and Buitrago and Camargo (2021) emphasize the importance of an appropriate institutional framework for international competitiveness.

Our motivation for this study is to analyze how institutional governance and business environment affect countries' competitiveness, their relative importance and their implications for Brazil.

We analyze the relationship between institutional governance (rule of law, control of corruption, political stability, regulatory quality and government effectiveness), business environment (factor conditions, demand conditions, related and support industries and context for rivalry) and the competitiveness of countries (productivity per worker) and seeks to answer the following questions:

- Q1. Does countries' institutional governance have a direct effect on their competitiveness?

- Q2. Does countries' institutional governance have an indirect effect on their competitiveness, through their business environments?

We have collected data from 131 countries related to these countries' institutional governance, business environment and competitiveness. For the analysis of the mentioned influences, the technique of partial least squares structural equations modeling (PLS-SEM) was used.

We hope that understanding how institutional governance and the business environment affect countries' competitiveness and their relative importance can be helpful for strategists and decision-makers in the quest to make their countries and companies internationally competitive.

After this introduction, the theoretical framework for the work together with the research methodology is presented, followed by analysis, discussion and conclusions.

\section{Theoretical framework}

\subsection{National competitiveness}

Several authors have tried to conceptualize and measure national competitiveness. Grein \& Craig (1996) identified the existence of a significant relationship between exports and national performance, with substantial differences between developing and industrialized countries. In emphasizing the importance of multinational activities on the competitiveness of South Korea and Singapore, Moon, Rugman and Verbeke (1998) used national productivity in terms of per capita production and production per unit of energy consumption as measures of competitiveness. 
Rugman, Oh and Lim (2012) used external sales at the company level as a measure of competitiveness. Bolouta and Pitelis (2014) considered the productivity of a country in terms of national production per unit of input, an excellent indicator of competitiveness. Berger (2008) identifies the ability of companies in a country to increase their productivity as essential for improving the economic standard of living of the citizens of that country. Porter (1998) defines national competitiveness in terms of aggregate productivity, while Snowdon (2011) considers that the existing business environments in each country have a significant influence on the performance of their companies.

Consistent with previous works that focus on productivity as the best indicator of national competitiveness, Hall and Jones (1999), Delgado, Ketels and Porter (2012), Porter, Delgado, Kettels and Stern (2008) and Fainshmidt, Smith \& Judge (2016) used gross domestic product (GDP) adjusted for purchasing power parity (PPP) per worker to address productivity and national competitiveness.

\subsection{Business environment and national competitiveness}

Following the structure-conduct-performance paradigm of industrial organization (Bain, 1959), Porter (1990) initially concluded that four elements interact with each other to determine the competitiveness of countries: factor conditions, demand conditions, related and support industries and context for rivalry (Diamond Model). Subsequently, Porter et al. (2008) defined that these same elements from the countries' business environment. For Zhang \& London (2013), this approach has become the most famous theory about the competitiveness of countries.

According to Porter (2009, p. 181), factor conditions refer to "the country's position regarding production factors such as qualified labor or infrastructure, necessary to compete in a given industry." Production factors include resources such as physical, human and financial resources available to economic entities, as well as the general quality of the infrastructure provided by their transport, communication, education and health systems. The author also emphasizes that advanced factors such as knowledge and human capital, are more critical to a country's competitiveness than basic factors. Research found that training and higher education have a positive impact on countries' prosperity (Barro, 2002; Krueger, \& Lindahl, 2001).

For Porter (2009), when domestic demand conditions are relatively sophisticated, domestic companies must react and improve their productive capacities. In this way, a sophisticated market would reward organizations for producing world-class products or services, as demanding consumers force organizations to become more sophisticated and, therefore, provide high national competitiveness.

Grant (2011) notes the importance of the characteristics of domestic demand in defining the differentiation of products and creating pressures for innovation and quality. In this sense, demanding and lead customers are considered partners in the innovation process (Porter et al., 2008). Snowdon (2011) points out that the sophistication of domestic demand is more important than its size.

The third element of the model addresses the importance of having sophisticated supplier groups and related industries in a country. According to Snowdon (2011), one of the most widespread discoveries in Porter's study is the tendency for successful companies to group in each country in clusters of related and support industries. As a result, economies that are external to companies and individual industries are internalized within the cluster. Grant (2011) points out that clusters' presence helps organizations migrate to emerging technologies and become or remain world-class. Thus, clusters provide knowledge, technology, enrich the economy and lead to increases in productivity. Kettels and Solvell (2006) observed that the presence and importance of clusters vary according to the state of 
RAUSP

57,1

economic development. In developing economies, they are less developed and companies tend to perform fewer activities in clusters.

Grant (2011) notes that, in Porter's conceptualization, the rivalry between companies is extremely significant to pressure them to cut costs, improve quality and innovate. In an environment with intense competition, continuous improvement is critical for high productivity and performance (Lewis, 2004; Porter and Sakakibara, 2004). Consequently, the domestic rivalry is fundamental to promoting competitiveness.

According to Porter et al. (2008), a high-quality business environment is characterized by vigorous local competition, demanding and sophisticated local customers, clusters instead of isolated companies and high quality, efficient and specialized inputs to the business.

The most frequent use of the Diamond Model is in case studies to assess the competitiveness of a single country (Fainshmidt, Smith, \& Judge, 2016). However, there are criticisms about this approach concerning precision and generalizability (Smit, 2010) and regarding the difficulties for its empirical evaluation because it is a system composed of interdependent elements (Davies and Ellis, 2000).

\subsection{Institutional governance and national competitiveness}

Institutions exert external controls over the behavior of individuals, organizations and the role of government in the economy (Cuervo-Cazurra, Mudambi, \& Pedersen, 2019) and their role in countries' competitiveness has become more analytically relevant in recent years (Buitrago and Camargo, 2021).

In this perspective, some institutional factors such as political stability, property rights and corruption control, can directly affect the competitiveness of countries and their business environments (Rugman et al., 2012). For Acemoglu and Robinson (2010), economic institutions such as market orientation and property rights are crucial for distinguishing between rich and stagnant countries. Zanello et al. (2016) emphasize the importance of the government's ability to form and efficiently allocate human capital in the economy.

Institutional governance quality is defined in terms of its pro-market characteristics such as laws and regulations that facilitate market relationships among economic players (Djankov et al., 2002; Khanna and Palepu, 2010).

Previous works found that institutional governance quality has a positive and significant impact on labor productivity. Hall and Jones (1999) found that institutional differences are the leading cause of differences in productivity and GDP per capita among 127 countries. According to Mustafa and Jamil (2018), government effectiveness and regulatory quality have a positive and significant impact on labor productivity in emerging Asian countries. For Olson, Sarna and Swamy (2000), institutional governance quality improves productivity growth in developing countries. Méon and Weill (2005) found that government efficiency is the governance quality indicator that has the most significant impact on labor productivity.

According to Singh and Pradham (2020), institutional governance quality has a positive impact on economic performance and governance indicators such as control of corruption, government effectiveness and political stability are vital for better economic performance in South Asian countries.

Huang, Wu, Yu and Zhang (2015) concluded that political instability leads to the suspicion that contractual obligations will not be honored in the long run and because of this, companies modify their resource allocation decisions. Pelletier and Bligh (2006) identified the positive effect of political stability on economic growth and development.

De Soto (2000) emphasizes the importance of legal and formal property systems, given that the protection of property rights is associated with more reliable and efficient economic activities, reducing uncertainty, opportunism and transaction costs. 
Transparency International (2020) defines corruption as the abuse of public power for private gain. Mo (2001) concluded that corruption reduces economic growth, entrepreneurship and innovation. Birhanu, Gambardella and Valentini (2016) concluded that bribery does not reduce companies' short-term performance but does commit investments in fixed assets, reflecting on their long-term growth. According to Fisman and Golden (2017), corruption undermines economic efficiency, increases social inequalities and is terrible for business and economic growth, eroding public confidence in political institutions.

Other studies confirmed the positive impact of the institutional governance quality on economic performance (Singh, 2019; Holmberg, Rothstein, \& Nasiritousi, 2009; Rajkumar \& Swaroop, 2008). Therefore, based on these considerations and to address the first question proposed in this article (Q1), Hypothesis $H 1$ comes out:

H1. The institutional governance quality of countries is positively associated with their competitiveness.

According to Porter (1998), government actions and other factors external to the Diamond Model would have an indirect influence on national competitiveness. This effect would occur through their influence on the business environment, which, in turn, would directly influence competitiveness.

In addition to confirming the relevance of the Diamond Model, Fainshmidt, Smith, \& Judge (2016) identified the institutional governance quality as another element of national competitiveness. The authors concluded that although a favorable position in the four elements of the Diamond Model can put a country in a more productive position, institutional governance quality leads to the strengthening of the Diamond (business environment) and provides cost reductions associated with instability, transactions and inappropriate political behavior.

Given this conclusion and based on previous studies on the positive effect of the quality of institutional governance on the productivity of countries (Hall \& Jones, 1999; Mustafa \& Jamil, 2018; Olson et al., 2000; Méon \& Weill, 2005) and also considering that previous studies have identified the positive effect of the business environment quality on countries' competitiveness (Porter, 1990; Porter et al., 2008), we hypothesize that the business environment quality mediates the relationship between the institutional governance quality and national competitiveness.

According to Hair, Hult, Ringle and Sarstedt (2017), the mediation effect occurs when a third construct intervenes between two other related constructs.

We suppose that a change in the exogenous construct (governance quality) would cause a change in the mediating construct (business environment quality), which, in turn, would result in a change in the endogenous construct (national competitiveness).

Based on this consideration and to address the second question proposed in this article (Q2), Hypothesis $H 2$ of this study comes out:

H2. Countries' business environment quality mediates the relationship between institutional governance quality and competitiveness.

Figure 1 illustrates the theoretical model proposed.

\section{Methodology}

We gathered data from 131 countries from 2019, as presented in Table 1 and used them to measure three latent variables: institutional governance quality, business environment quality and competitiveness of these countries. The data were obtained from the following sources: World Development Indicators (World Bank, 2019b), Worldwide Governance 
RAUSP

57,1

54

Figure 1.

Theoretical model

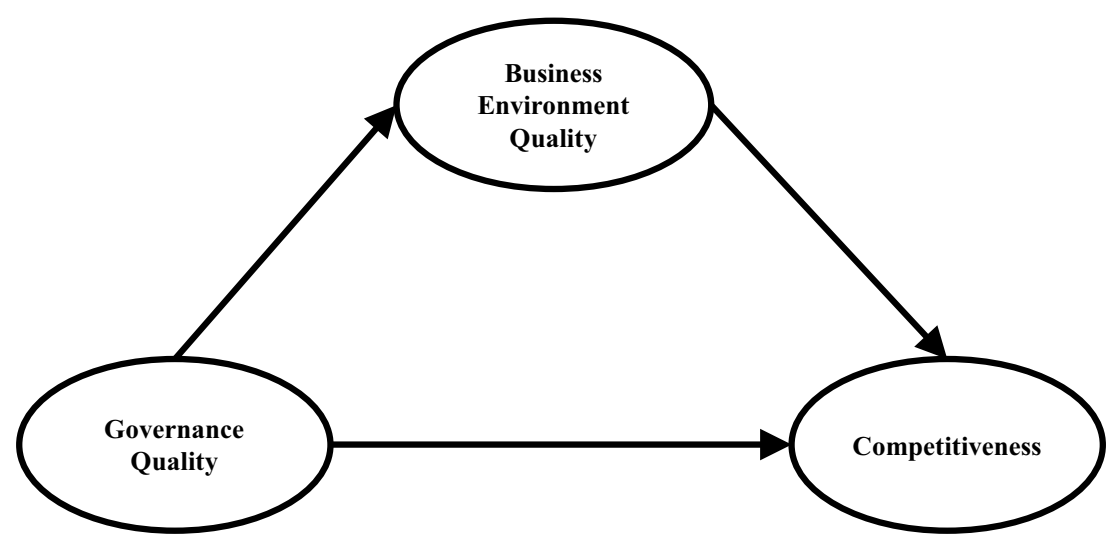

Source: Elaborated by the author

Indicators World Bank (2019a) and Executive Opinion Poll of the World Economic Forum (World Economic Forum, 2019). All countries for which the necessary data were available were included in the survey.

Considering that productivity is an essential element of national competitiveness, as in previous works by Hall and Jones (1999), Delgado et al. (2012), Porter et al. (2008) and Fainshmidt, Smith and Judge (2016), the GDP data adjusted by the PPC per worker were used as a measure of countries' competitiveness. We used data for 2019 provided by the World Bank (World Bank, 2019b) and Executive Opinion Poll of the World Economic Forum (World Economic Forum, 2019). The GDP (PPC) per worker, that is, labor productivity is measured when GDP (PPC) is divided by used people over 15 years old.

To measure institutional governance quality, we used Worldwide Governance Indicators for 2019 (World Bank, 2019a). Indicators for political stability, the rule of law, government effectiveness, voice and accountability, regulatory quality and control of corruption for the countries surveyed were used as indicated in Table 2.

These indicators are a research data set summarizing the views on the quality of institutional governance provided by many enterprises, citizens and experts survey respondents in the countries in this research. These data are gathered from several survey institutes, think tanks, non-governmental organizations, international organizations and private sector firms. The governance data for each indicator ranges from approximately -2.5 (low quality) to 2.5 (high quality), reflecting governance performance for each country.

Data relating to Business Environment quality were obtained from the World Economic Forum's Executive Opinion Survey for 2019 (World Economic Forum, 2019), included in the 2019 Global Competitiveness Report. Each indicator is measured on a seven-point Likert scale, with 7 indicating high business environment quality regarding that indicator (Table 3).

Considering that advanced factors such as knowledge and human capital, are more critical to a country's competitiveness than basic factors (Porter, 2009; Barro, 2002; Krueger \& Lindahl, 2001), we used as measures of factor conditions the skillset of secondary-education graduates, the skillset of university graduates and the quality of vocational training for each country.

To measure the demand conditions, we used the buyer sophistication measure for each country (Porter, 2009; Porter et al., 2008; Snowdon, 2011). As a measure of related and 


\begin{tabular}{|c|c|c|}
\hline Income group & Country & $\begin{array}{l}\text { Business } \\
\text { environment }\end{array}$ \\
\hline \multirow[t]{2}{*}{ High income } & $\begin{array}{l}\text { Australia, Austria, Bahrain, Belgium, Brunei, Canada, Chile, Croatia and Cyprus } \\
\text { Czech Rep., Denmark, Estonia, Finland, France, Germany, Greece and Hong } \\
\text { Kong } \\
\text { Hungary, Iceland, Ireland, Israel, Italy, Japan, Korea, Rep., Kuwait, Latvia and } \\
\text { Lithuania } \\
\text { Luxembourg, Malta, Mauritius, the Netherlands, New Zealand, Norway, Oman } \\
\text { and Panama }\end{array}$ & $\begin{array}{r}\text { mediating } \\
\text { effect }\end{array}$ \\
\hline & $\begin{array}{l}\text { Poland, Portugal, Qatar, Romania, Saudi Arabia, Singapore, Slovak Republic and } \\
\text { Spain } \\
\text { Slovenia, Sweden, Switzerland, Trinidad and Tobago and the United Arab } \\
\text { Emirates } \\
\text { UK, USA and Uruguay }\end{array}$ & \\
\hline Upper middle income & $\begin{array}{l}\text { Albania, Argentina, Armenia, Azerbaijan, Bosnia and Herzegovina and } \\
\text { Botswana } \\
\text { Brazil, Bulgaria, China, Colombia, Costa Rica, Dominican Republic, Ecuador and } \\
\text { Georgia } \\
\text { Guatemala, Indonesia, Jamaica, Jordan, Kazakhstan, Lebanon, Malaysia and } \\
\text { Mexico } \\
\text { Montenegro, Namibia, Paraguay, Peru, Russian Federation, Serbia and South } \\
\text { Africa } \\
\text { Thailand and Turkey }\end{array}$ & \\
\hline Lower middle income & $\begin{array}{l}\text { Algeria, Angola, Bangladesh, Benin, Bolivia, Cambodia, Cameroon and Cape } \\
\text { Verde } \\
\text { Côte d'Ivoire, Egypt, El Salvador, Eswatini, Ghana, Honduras, India, Kenya and } \\
\text { Nepal } \\
\text { Kyrgyz Republic, LAO PDR, Mauritania, Moldova, Mongolia, Morocco and } \\
\text { Nicaragua } \\
\text { Nigeria, Pakistan, Philippines, Senegal, Sri Lanka, Tanzania, Tunisia, Ukraine } \\
\text { and Zambia }\end{array}$ & \\
\hline Low income & $\begin{array}{l}\text { Burkina Faso, Burundi, Chad, Congo, Dem. Rep., Ethiopia, Gambia, Guinea and } \\
\text { Haiti } \\
\text { Madagascar, Malawi, Mali, Mozambique, Rwanda, Tajikistan, Uganda and } \\
\text { Zimbabwe }\end{array}$ & $\begin{array}{r}\text { Table } 1 . \\
\text { Countries surveyed }\end{array}$ \\
\hline Source: Elaborated by & ne author from World Bank (2019b) & \\
\hline
\end{tabular}

supporting industries, we used the state of cluster development data for each country (Porter, 2009; Kettels \& Solvell, 2006). Finally, as a measure of the context for rivalry in each country, we used the extent of market dominance, the competition in professional services and the competition in retail services data (Lewis, 2004; Porter \& Sakakibara, 2004).

To test the influence of institutional governance quality on the business environment quality $(\mathrm{HI})$ and the mediation effect of the business environment quality on the relationship between institutional governance quality and competitiveness of countries (H2), we used the PLS-SEM technique.

According to Hair et al. (2019), the technique of PLS-SEM has considered suitable for use in applied social science works for the following reasons:

- works efficiently with small sample sizes and complex models;

- does not require normal data distribution; and

- can easily handle reflective and formative measurement models, as well as single item constructions. 
RAUSP

57,1

56
Indicator

Voice and accountability

Political Stability and absence of violence/terrorism

Government effectiveness

Regulatory quality

Rule of law

\section{Table 2.}

Quality of countries' institutional

Control of corruption

governance indicators used in the research

Source: World Bank (2019a)
Reflects perceptions of the extent to which a country's citizens can participate in selecting their government, as well as freedom of expression, freedom of association, and a free media

Political Stability and Absence of Violence/Terrorism measures perceptions of the likelihood of political instability and/or politically motivated violence, including terrorism

Reflects perceptions of the quality of public services, the quality of the civil service and the degree of its independence from political pressures, the quality of policy formulation and implementation, and the credibility of the government's commitment to such policies

Reflects perceptions of the ability of the government to formulate and implement sound policies and regulations that permit and promote private sector development

Reflects perceptions of the extent to which agents have confidence in and abide by the rules of society, and in particular the quality of contract enforcement, property rights, the police, and the courts, as well as the likelihood of crime and violence

Reflects perceptions of the extent to which public power is exercised for private gain, including both petty and grand forms of corruption, as well as "capture" of the state by elites and private interests

For Cepeda, Nitzl and Roldán (2018), the PLS-SEM is one of the options used to analyze mediation effects. Given that in this research, $H 2$ refers to a case in which there is a mediation effect, the analysis technique using PLS-SEM is adequate.

One limitation of this technique is that it cannot be applied when structural models contain causal loops or circular relationships between latent variables (Hair et al., 2017). Being aware of this, instead of using the original Diamond Model, which presents such circular relationships, we used the business environment construct, composed of elements of the Diamond Model.

Another possible bias regarding the goodness of fit, the PLS-SEM technique relies much less on the concept of model fit in comparison with confirmatory-based structural equation modeling (CB-SEM). As a result, some researchers make a mistake by incorrectly concluding that PLS-SEM is not valid for theory testing and confirmation (Hair et al., 2019).

Finally, as parameter estimates with PLS-SEM are not optimal regarding consistency, this characteristic is often incorrectly referred to as PLS-SEM bias (Hair et al., 2017).

\section{Analysis}

To measure the convergent validity of the model, the results of the extracted average variance (AVE) (above 0.5) were observed, together with Cronbach's alpha (above 0.7) and the composite reliability (above 0.6) (Hair et al., 2019). The results presented in Table 4 confirm the convergent validity, showing that the observed items converged to form the research constructs.

The discriminant validity included the calculation of the Heterotrait-Monotrait ratio (HTMT). We found that all HTMT values are below the limit value of 0.85 (Hair et al., 2019). We also found that HTMT values are significantly different from 1 by performing the bootstrapping procedure. The results are shown in Table 4 and confirm the discriminant validity, proving that all the research constructs discriminate among themselves. 
$\frac{\text { Item }}{\text { Skillset of secondary-education graduates }}$

Skillset of university graduates

Extent of market dominance

Competition in professional services

Competition in retail services

Quality of vocational training

State of cluster development

Buyer Sophistication

Source: World Economic Forum (2019)
Question

Response to the survey question "In your country, to what extent do secondary-education graduates possess the skills needed by businesses?" [1 = not at all; $7=$ to $a$ great extent]

Response to the survey question "In your country, to what extent do university graduates possess the skills needed by businesses?" [1 = not at all; $7=$ to a great extent]

Response to the survey question "In your country, how do you characterize corporate activity?" $[1=$ dominated by a few business groups; 7 = spread among many firms] Response to the survey question "In your country, how competitive is the provision of professional services (legal services, accounting, engineering, etc.) $[1=$ not at all competitive; 7 = extremely competitive]"

Response to the survey question "In your country, how competitive is the provision of retail services" [1 = not at all competitive; 7 = extremely competitive]

Response to the survey question "In your country, how do you assess the quality of vocational training?" [1 = extremely poor among the worst in the world; $7=$ excellent among the best in the world]

Response to the survey question "In your country, how widespread are well-developed and deep clusters (geographic concentrations of firms, suppliers, producers of related products and services, and specialized institutions in a particular field)?" [1 = non-existent; 7 = widespread in many fields]

Response to the survey question: "In your country, how do buyers make purchasing decisions?" [1 = based solely on the lowest price; $7=$ based on a sophisticated analysis of performance atributes]

\section{Business environment mediating effect}

Table 3.

Items used for measuring countries' quality of business environment

The results of VIF values for the business environment (2.508) and governance (2.508) as predictors of competitiveness are below the threshold of 5 . Therefore, collinearity among the predictor constructs is not a critical issue in the structural model.

The $R^{2}$ values obtained for the endogenous latent variables were 0.601 for competitiveness and business environment. These results indicate that the model's predictive power can be considered moderate.

The effect size $f^{2}$ is used to evaluate whether one omitted exogenous construct has a substantive impact on the endogenous constructs. The effect sizes $f^{2}$ to structural model relationships obtained are as follows: business environment on competitiveness (0.081) (considered small); institutional governance on competitiveness (0.285) (considered large); institutional governance on the business environment (1.508) (considered large).

Examining the relative importance of path coefficients, we found that the institutional governance effect on the business environment is the most important (0.775), followed by its effect on competitiveness (0.534). The least important effect found was that of the business environment on competitiveness (0.284). 
RAUSP

57,1

58

Table 4.

Results summary
To assess whether structural model relationships are significant, we ran the bootstrapping procedure. Table 5 shows $p$ values for the structural model relationships as a result of the bootstrapping procedure. Assuming a 5\% significance level, we find that all relationships in the structural model are significant.

Table 6 shows $p$ values for the structural model relationships' total effects resulting from the bootstrapping procedure. Again, assuming a 5\% significance level, we find that all relationships in the structural model are significant.

After running a blindfolding procedure, we found that $\mathrm{Q}^{2}$ values for competitiveness $(0.589)$ and business environment (0.430) are considerably above zero. These results provide clear support for the model's predictive relevance regarding these endogenous latent variables.

\section{Discussion}

To answer the first question of this study (Q1) we established the institutional governance quality construct. In addition, we also established a construct to represent competitiveness based on productivity. Establishing these constructs made it possible to test our first hypothesis (H1) by using the structural equation modeling technique.

The results (Tables 4 and 5) confirm a positive and significant influence of institutional governance quality on countries' competitiveness (path coefficient 0.534 ), as in results from

\begin{tabular}{|c|c|c|c|c|c|c|}
\hline $\begin{array}{l}\text { Latent } \\
\text { Variable }\end{array}$ & Indicators & Loadings & $\begin{array}{l}\text { Indicator } \\
\text { Reliability }\end{array}$ & AVE & $\begin{array}{l}\text { Composite } \\
\text { Reliability }\end{array}$ & $\begin{array}{c}\text { Cronbach's } \\
\text { Alpha }\end{array}$ \\
\hline Business & Buyer sophistication & 0.837 & 0.701 & 0.731 & 0.956 & 0.947 \\
\hline Environment & $\begin{array}{l}\text { Competition in professional } \\
\text { services }\end{array}$ & 0.765 & 0.585 & & & \\
\hline \multirow[t]{6}{*}{ Quality } & Competition in retail & 0.752 & 0.566 & & & \\
\hline & Extent of market dominance & 0.872 & 0.760 & & & \\
\hline & Quality of vocational training & 0.903 & 0.815 & & & \\
\hline & $\begin{array}{l}\text { Skillset of secondary-education } \\
\text { graduates }\end{array}$ & 0.916 & 0.839 & & & \\
\hline & Skillset of university graduates & 0.895 & 0.801 & & & \\
\hline & State of cluster development & 0.883 & 0.780 & & & \\
\hline Governance & Government effectiveness & 0.970 & 0.941 & 0.855 & 0.972 & 0.965 \\
\hline \multirow[t]{5}{*}{ Quality } & Political stability & 0.832 & 0.692 & & & \\
\hline & Regulatory quality & 0.965 & 0.931 & & & \\
\hline & Rule of law & 0.978 & 0.956 & & & \\
\hline & Accountability & 0.820 & 0.672 & & & \\
\hline & Control of corruption & 0.968 & 0.937 & & & \\
\hline
\end{tabular}

Source: Elaborated by the author based on the SmartPLS output
Table 5.

Significance testing of structural model path coefficients

\begin{tabular}{lcccc}
\hline Relationship & Path coef. & $p$ values & $95 \%$ conf intervals & $\begin{array}{c}\text { Significance } \\
(p<0.05)\end{array}$ \\
\hline Business environment-competitiveness & 0.284 & 0.002 & $0.089-0.458$ & Yes \\
Governance-competitiveness & 0.534 & 0.000 & $0.365-0.679$ & Yes \\
Governance-business environment & 0.775 & 0.000 & $0.710-0.825$ & Yes \\
Source: Elaborated by the author based on the SmartPLS output & & \\
\hline
\end{tabular}


previous studies (Hall \& Jones,1999; Mustafa \& Jamil, 2018; Olson et al., 2000; Méon \& Weill, 2005).

In addition to this direct effect, we also investigated an indirect effect of institutional governance quality on competitiveness, based on the theory that such effect occurs because of the business environment (Porter et al., 2000; Fainshmidt, Smith and Judge, 2016).

By establishing and testing our second hypothesis (H2), it was possible to address our second question (Q2) using the structural equation modeling technique. The results (Tables 4 and 5) confirm a positive and significant influence of institutional governance quality on countries' business environment quality (path coefficient 0.775 ), which confirms previous findings that institutional governance quality leads to the strengthening of Diamond Model elements (Fainshmidt, Smith and Judge, 2016). This positive effect occurs due to reducing transaction costs, instability and inappropriate political behavior, allowing companies not to spend their time and resources dealing with instability and uncertainties (Fainshmidt, Smith and Judge, 2016).

The results also confirm a positive and significant influence of the business environment quality on countries' competitiveness (path coefficient 0.284 ), confirming previous findings (Porter, 1990; Porter et al., 2008).

As indicated in Table 6, the total indirect effect (path coefficient 0.220) and the direct effect (path coefficient 0.534) are both significant and point in the same direction. Therefore, the total effect of institutional governance quality on countries' competitiveness is positive and significant (Table 6). The direct effect of the business environment quality on countries' competitiveness was the least significant of the direct effects found (path coefficient 0,284 ).

Our results indicate that institutional governance quality plays a central role in countries' competitiveness, as it positively affects competitiveness and the business environment. Institutional governance quality (exogenous construct) has a positive effect on business environment quality (mediating variable), which, in turn, has a positive effect on competitiveness (endogenous construct). As all these effects are positive and add to the positive effect of governance quality on competitiveness, it was possible to verify the existence of a complementary mediation effect (Hair, Hult, Ringle, \& Sarstedt, 2017). Thus, the effect of the business environment quality on competitiveness acts as a reinforcement of the effect of the governance quality on competitiveness.

Among the external weights (Table 7) related to institutional governance quality, we found that government effectiveness and corruption control are the main ones, as in previous findings (Singh \& Pradhan, 2020; Méon \& Weill, 2005). Regarding external weights (Table 7) related to business environment quality, we observe that education indicators have the highest weights, also confirming previous findings (Barro, 2002; Krueger \& Lindahl, 2001).

Table 8 illustrates Brazil's business environment quality indicators in relation to the various income groups.

\begin{tabular}{lcccc}
\hline Effect & Path coef. & $p$ values & $95 \%$ conf intervals & $\begin{array}{c}\text { Significance } \\
(p<0.05)\end{array}$ \\
\hline Direct effect & 0.534 & 0.000 & $0.365-0.679$ & Yes \\
Indirect effect & 0.220 & 0.003 & $0.069-0.357$ & Yes \\
Total effect & 0.754 & 0.000 & $0.661-0.818$ & Yes
\end{tabular}

Source: Elaborated by the author based on the SmartPLS output

Table 6.

Significance of direct, indirect and total effects of governance on competitiveness 
RAUSP

57,1

60

Regarding the indicators with the highest outer weights (Table 7), that correspond to the advanced factors such as human capital, Brazil has its worst relative positions in the uppermiddle-income group.

It is noteworthy that the country spends more on education, with worse results on learning verification exams than other countries (Lisboa, 2020; Begnini \& Tosta, 2017).

Considering the governance indicators, Table 9 illustrates Brazil's position in relation to the different income groups.

\begin{tabular}{lcc}
\hline Indicator & Business environment & Governance \\
\hline $\begin{array}{l}\text { Competition in retail } \\
\text { Control of corruption }\end{array}$ & 0.128 & 0.196 \\
$\begin{array}{l}\text { Extent of market dominance } \\
\text { Government effectiveness }\end{array}$ & 0.142 & 0.207 \\
Labor productivity & & 0.148 \\
Political stability & & 0.195 \\
Quality of vocational & 0.157 & 0.199 \\
Regulatory quality & & \\
Rule of law & 0.160 & \\
Skillset of graduates & 0.148 & \\
Skillset of university graduates & 0.148 & \\
State of cluster & &
\end{tabular}

Table 7.

Outer weights

Source: Elaborated by the author based on SmartPLS output

\begin{tabular}{lccccc}
\hline Indicator & High income & Upper middle & Brazil & Lower middle & Low income \\
\hline Buyer sophistication & 4.11 & 3.57 & 3.59 & 3.19 & 2.91 \\
Competition in professional services & 5.41 & 5.13 & 5.20 & 4.49 & 4.01 \\
Competition in retail & 5.52 & 5.17 & 5.32 & 4.85 & 4.59 \\
Extent of market dominance & 4.34 & 3.73 & 3.77 & 3.45 & 3.29 \\
Quality of vocational training & 4.67 & 4.03 & 3.32 & 3.75 & 3.72 \\
Skillset of graduates & 4.66 & 3.99 & 3.20 & 3.72 & 3.65 \\
Skillser of univ. graduates & 4.94 & 4.28 & 3.51 & 4.02 & 3.99 \\
State of cluster development & 4.38 & 3.78 & 3.92 & 3.51 & 3.26 \\
Source: Elaborated by the author from World Bank (2019b) and World Economic Forum (2019) \\
\hline
\end{tabular}

\section{Table 9.}

Governance quality indicators $(0-100)$ by countries income group versus Brazil

\begin{tabular}{lccccc}
\hline Indicator & High income & Upper middle & Brazil & Lower middle & Low income \\
\hline Voice and accountability & 87.24 & 48.49 & 58.62 & 42.07 & 25.62 \\
Political stability & 74.75 & 49.99 & 24.76 & 39.46 & 22.95 \\
Government effectiveness & 87.59 & 50.85 & 43.75 & 34.21 & 20.51 \\
Regulatory quality & 88.86 & 49.09 & 48.08 & 34.21 & 20.51 \\
Rule of law & 87.41 & 48.92 & 47.60 & 34.86 & 20.37 \\
Control of corruption & 85.33 & 48.43 & 42.31 & 36.92 & 21.09 \\
Source: Elaborated by the author from World Bank (2019a) & & & \\
\hline
\end{tabular}


Regarding government effectiveness, which is the indicator with the highest outer weight (Table 7), Brazil performs below the average of the group of high-middle-income countries.

In fact, the Brazilian public sector costs about 33\% more than that of other emerging countries, its judiciary costs between 4 and 10 times more than other emerging and developed countries (Lisboa, 2020). In addition, legal uncertainty and tax complexity make life difficult for companies and hamper investments (Giambiagi \& Zeidan, 2018).

The worst relative performance in Brazil (Table 9) associates with political stability. There is an inferior performance of the country in relation to the group of upper-middleincome countries and in relation to the lower-middle-income countries. Its performance can be comparable to the performance of low-income countries.

Regarding the other indicators, i.e. corruption control, the rule of law and regulatory quality, we observed that the country generally performs below the average of the uppermiddle-income group (Table 9).

\section{Conclusion}

We believe that this study contributes to the literature by providing a better understanding of how institutional governance quality and business environment quality affect the competitiveness of countries and the relative importance of each one.

The empirical results indicate that institutional governance quality positively affects countries' competitiveness and business environment quality. We found support for the presence of a complementary mediating effect of the business environment quality and also for institutional governance as the main factor for countries' competitiveness.

For strategists and decision-makers, understanding these effects on countries' competitiveness and their relative importance is fundamental to perceiving what makes their companies internationally competitive. Moreover, the prominence of institutional governance for the competitiveness of countries means that the presence and appreciation of institutional governance quality need to be valued by society.

Brazil has poor governance quality indicators compared to high-middle-income countries, especially regarding government effectiveness, political stability and control of corruption. Therefore, our findings indicate that for the country to improve its competitiveness, its priority should be to seek an improvement in these indicators, which would have a direct effect on the country's competitiveness and on the business environment quality, which, in turn, would also lead to a positive effect on competitiveness.

One limitation of this study is that the research was restricted to data related to the year 2019. As a suggestion for new studies, it would be interesting to carry out research that included more years' data, which would make it possible to verify the consistency of the results over time.

\section{References}

Acemoglu, D., \& Robinson, J. (2010). The role of institutions in growth and development. Review of Economics and Institutions, 1(2), 1-33. doi: https://doi.org/10.5202/rei.vli2.14.

Bain, J. S. (1959). Industrial organization, New York, NY: Wiley.

Barro, R. J. (2002). Education as a determinant of economic growth. In E. Lazear, ed. Education in the Twenty-First century, Stanford, CA: Hoover Institute.

Begnini, S., \& Tosta, H. T. (2017). A eficiência dos gastos públicos com a educação fundamental no brasil: uma aplicação da análise envoltória de dados (DEA). E\&G Economia e Gestão, 17 No. (46)

Berger, T. (2008). Concepts on national competitiveness. Journal of International Business and Economy, 9(1), 3-17. doi: https://doi.org/10.51240/jibe.2008.1.5. 
RAUSP

57,1

Birhanu, A. G., Gambardella, A., \& Valentini, G. (2016). Bribery and investment: firm-level evidence from Africa and Latin America. Strategic Management Journal, 37(9), 1865-1877. doi: https://doi. org/10.1002/smj.2431.

Bolouta, I., \& Pitelis, C. N. (2014). Who needs CSR? The impact of corporate social responsibility on national competitiveness. Journal of Business Ethics, 119(3), 349-364. doi: https://doi.org/ 10.1007/s10551-013-1633-2.

Buitrago, R. E., \& Camargo, M. I. B. (2021). Institutions, institutional quality, and international competitiveness: review and examination of future research directions. Journal of Business Research, 128, 423-435.

Cepeda, G., Nitzl, C., \& Roldán, J. L. (2018). Mediation analyses in partial least squares structural equation modeling. H. Latan, \& R. Noonan, (Eds). Partial least squares path modeling: Basic concepts, methodological issues and applications, Heidelberg: Springer. In

Cuervo-Cazurra, A., Mudambi, R., \& Pedersen, T. (2019). Clarifying the relationships between institutions and global strategy. Global Strategy Journal, 9(2), 151-175. doi: https:/doi.org/10.1002/gsj.1342.

Davies, H., \& Ellis, P. (2000). Porter"s competitive advantage of nations: time for the final judgment? Journal of Management Studies, 37(8), 1189-1214. doi: https://doi.org/10.1111/1467-6486.00221.

Delgado, M., Ketels, C., \& Porter, M. E. (2012). \& Stern, S. The determinants of national competitiveness. Working Paper, Cambridge: MA: National Bureau of Economic Research. Retrieved from: http://www.nber.org/papers/w18249.

De Soto, H. (2000). The mistery of Capital: Why capitalism triumphs in the west and fails everywhere else, New York, NY: Basic Books.

Djankov, S., La Porta, R., Lopez-de-Silanes, F., \& Sheifer, A. (2002). The regulation of entry. The Quarterly Journal of Economics, 117(1), 1-37. doi: https://doi.org/10.1162/003355302753399436.

Fainshmidt, S., Smith, A., \& Judge, W. Q. (2016). National competitiveness and porter's diamond model: the role of MNE penetration and governance policy. Global Strategy Journal, 6(2), 81-104. doi: https://doi.org/10.1002/gsj.1116.

Fisman, R., \& Golden, M. A. (2017). Corruption: what everyone needs to know, Oxford University Press.

Giambiagi, F., \& Zeidan, R. (2018). Apelo à razão; a reconciliação com a lógica econômica, Rio de Janeiro: Record.

Grant, R. M. (2011). National economic development and the competitive advantage of nations. R. Huggins, \& H. Izushi, (Eds), Competition, competitive advantage, and clusters: the ideas of Michael porter, Oxford University Press. In

Grein, A. F., \& Craig, C. S. (1996). Economic performance over time: does porter"s diamond hold at the national level? The International Executive, 38(3), 303-322. doi: https://doi.org/10.1002/tie.5060380304.

Hair, J. F., Hult, G. T. M., Ringle, C. M., \& Sarstedt, M. (2017). A primer on partial least squares structural equation modeling (PLS-SEM), 2nd ed., Thousand Oaks, CA: Sage.

Hair, J. F., Risher, J. J., Sarstedt, M., \& Ringle, C. M. (2019). When to use and how to report the results of PLS-SEM. European Business Review, 31(1), 2-24. doi: https://doi.org/10.1108/EBR-11-2018-0203.

Hall, R. E., \& Jones, C. I. (1999). Why do some countries produce so much more output per worker than others?. Working Paper, Cambridge, MA: National Bureau of Economic Research, Retrieved from http://www.nber.org/papers/w6564

Holmberg, S., Rothstein, B., \& Nasiritousi, N. (2009). Quality of government: What you get. Annual Review of Political Science, 12(1), 135-161. doi: https://doi.org/10.1146/annurev-polisci-100608-104510.

Huang, T., Wu, F., Yu, J., \& Zhang, B. (2015). Political risk and dividend policy: evidence from international political crises. Journal of International Business Studies, 46(5), 574-595. doi: https://doi.org/10.1057/jibs.2015.2.

Kauffmann, D., Kraay, A., \& Zoido-Lobatón, P. (1999). Governance matters., 1-61. World Bank Policy Research, Working Paper, 2196, 
Khanna, T., \& Palepu, K. (2010). Winning in emerging markets: a road map for strategy and execution, Boston, MA: Harvard Business School Press.

Kettels, C., \& Solvell, O. (2006). Clusters in the EU-10 new member countries, Brussels: European Commission, DG Enterprise and Industry.

Krueger, A., \& Lindahl, M. (2001). Education for growth: why and for whom? Journal of Economic Literature, 39(4), 1101-1136. doi: https://doi.org/10.1257/jel.39.4.1101.

Landes, D. (1998). A riqueza e a pobreza das nações: porque algumas nações são tão ricas e outras tão pobres, Rio de Janeiro: Campus.

Lee, C. (2010). An institutional perspective of national competitiveness. The Singapore Economic Review, 55(04), 671-683. doi: https://doi.org/10.1142/S0217590810004000.

Lewis, W. W. (2004). The power of productivity, Chicago, IL: University of Chicago Press.

Lisboa, M. (2020). Reforma do estado no contexto da pandemia do coronavírus. F. Giambiagi, S. G. Ferreira, \& A. M. H. Ambrósio, (Eds), Reforma do estado brasileiro, São Paulo: Atlas. In

Méon, P.-G., \& Weill, L. (2005). Does better governance foster efficiency? An aggregate frontier analysis. Economics of Governance, 6(1), 75-90. doi: https://doi.org/10.1007/s10101-004-0080-z.

Mo, P. H. (2001). Corruption and economic growth. Journal of Comparative Economics, 29(1), 66-79. doi: https://doi.org/10.1006/jcec.2000.1703.

Moon, H., Rugman, A. M., \& Verbeke, A. (1998). A generalized double diamond approach to the global competitiveness of korea and Singapore. International Business Review, 7(2), 135-150. doi: https://doi.org/10.1016/S0969-5931(98)00002-X.

Mustafa, G., \& Jamil, M. \&, (2018). Testing the Governance-Productivity nexus for emerging asian countries. The Lahore Journal of Economics, 23(1), 143-169. doi: https://doi.org/10.35536/lje.2018.v23.i1.A6.

North, D. C. (1990). Institutions, Institutional Change, and Economic Performance, Cambridge: Cambridge University Press.

Olson, M., Sarna, N., \& Swamy, A. V. (2000). Governance and growth: a simple hypothesis explaining Cross-Country differences in productivity growth. Public Choice, 102(3/4), 341-364. doi: https:// doi.org/10.1023/A:1005067115159.

Pelletier, K. L., \& Bligh, M. C. (2006). Rebounding from corruption: perceptions of ethics program effectiveness in a public sector organization. Journal of Business Ethics, 67(4), 359-374. doi: https://doi.org/10.1007/s10551-006-9027-3.

Porter, M. E. (1990). The competitive advantage of nations, New York, NY: The Free Press.

Porter, M. E. (1998). Location, clusters, and the 'new' microeconomics of competition. Business Economics, 33(1), 7-13.

Porter, M. E. (2009). Competição, Rio de Janeiro: Elsevier.

Porter, M. E., \& Sakakibara, M. (2004). Competition in Japan. Journal of Economic Perspectives, 18(1), 27-50. doi: https://doi.org/10.1257/089533004773563421.

Porter, M. E. Delgado, M. Kettels, C., \& Stern, S. (2008). Moving to a new global competitiveness index. Global competitiveness report 2009. Geneva: World Economic Forum, 43-63.

Rajkumar, A. S., \& Swaroop, V. (2008). Public spending and outcomes: Does governance matter? Journal of Development Economics, 86(1), 105-127. doi: https://doi.org/10.1016/j.jdeveco.2007.08.003.

Rugman, A. M., Oh, C. H., \& Lim, D. S. K. (2012). The regional and global competitiveness of multinational firms. Journal of the Academy of Marketing Science, 40(2), 2018-2235. doi: https:// doi.org/10.1007/s11747-011-0270-5.

Singh, B. P. (2019). Does governance matter: Evidence from BRICS. Global Business Review, Retrieved from: https://doi.org/10.1177/0972150919861222.

Singh, B. P., \& Pradhan, K. C. (2020). Institutional quality and economic performance in South asia. Journal of Public Affairs. Retrieved from https://doi/10.1002/pa.2401 
RAUSP

57,1

Smit, A. J. (2010). The competitive advantage of nations: is porter"s diamond framework a new theory that explains the international competitiveness of countries? Southern African Business Review, 14(1), 105-130.

Snowdon, B. (2011). The growth and competitiveness of nations: Porter"s contribution. nR. Huggins, \& H. Izushi, (Eds), Competition, Competitive Advantage, and Clusters: the Ideas of Michael Porter, Oxford University Press. I

Tallman, S., \& Pedersen, T. (2015). What is international strategy research and what is not. Global Strategy Journal, 5(4), 273-227. doi: https://doi.org/10.1002/gsj.1104.

Transparency International (2020), What is corruption?. Retrieved from www.transparency.org/en/ what-is-corruption (accessed 30 September 2020).

World Bank (2019a). Worldwide governance indicators. Retrieved from https://info.worldbank.org/ governance/wgi/ (accessed 3 August 2020).

World Bank (2019b). World development indicators. Retrieved from https://databank.worldbank.org/ reports.aspx?source=2\&series=SL.GDP.PCAP.EM.KD (accessed 7 August 2020).

World Economic Forum (2019). The global competitiveness report, 2019. Retrieved from www. weforum.org/reports/global-competitiveness-report-2019 (accessed 20 July 2020).

Zanello, G., Fu, X., Mohnen, P., \& Ventresca, M. (2016). The creation and diffusion of innovation in developing countries: a systematic literature review. Journal of Economic Surveys, 30(5), 884-912. doi: https://doi.org/10.1111/joes.12126.

Zhang, P., \& London, K. (2013). Towards an internationalized sustainable industrial competitiveness model. Competitiveness Review, 23(2), 95-113. doi: https://doi.org/10.1108/10595421311305325.

Author contributions are as follows: Bontempo, Paulo - Conceptualization (Lead); Data curation (Lead); Formal analysis (Lead); Funding acquisition (Lead); Investigation (Lead); Methodology (Lead); Project administration (Lead); Resources (Lead); Software (Lead); Supervision (Lead); Validation (Lead); Visualization (Lead); Writing-original draft (Lead); Writing-review \& editing (Lead).

Corresponding author

Paulo Bontempo can be contacted at: Paulo.bontempo@unialfa.com.br

Asociate editor: Paula Schnaider

For instructions on how to order reprints of this article, please visit our website:

www.emeraldgrouppublishing.com/licensing/reprints.htm

Or contact us for further details: permissions@emeraldinsight.com 